\title{
The effect of prophylactic dose of a low molecular weight heparin on skin wound healing of rats ${ }^{1}$
}

\author{
Efeito da dose profilática de heparina de baixo peso molecular na cicatrização de feridas na pele \\ de ratos
}

\author{
Ozdamar Fuad Oken', Ahmet Ozgur Yildirim', Murat Gulcek ${ }^{\mathrm{II}}$, Vuslat Sema Unal', Akin Karakuyu', Korhan Ozlu', Ahmet \\ Ucaner ${ }^{\text {III }}$
}

${ }^{\mathrm{I}} \mathrm{MD}$, Resident, Department of $1^{\text {st }}$ Orthopedics and Traumatology, Ankara Numune Research and Training Hospital, Turkey.

${ }^{\text {II }} \mathrm{MD}$, Associate Professor, Department of $1^{\text {st }}$ Orthopedics and Traumatology, Ankara Numune Research and Training Hospital, Turkey.

${ }^{\text {III }}$ MD, Head of Department, Department of $1^{\text {st }}$ Orthopedics and Traumatology, Ankara Numune Research and Training Hospital, Turkey.

\begin{abstract}
Purpose: To investigate the effect of prophylactic dose of a low molecular weight heparin, enoxaparin, on skin wound healing of rats. Methods: Forty rats were used for the study. Rats were randomly assigned to two equal groups. Experimental group received prophylactic dose of enoxaparin. Physiologic saline was administered to the control group. Parameters of wound healing of experimental and control groups were compared. For comparison of the groups in terms of fibrosis, vascularization, inflammation, epithelization, and tensile strength test (Newton). Mann-Whitney-U test was used because variables were categorical data (fibrosis, vascularization, inflammation and epithelization). Differences between groups were analyzed with independent samples $t$-test (tensile strength). Significance was set at $p<0.05$. Results: Skin wound of the experimental group presented tensile strength significantly decreased $(\mathrm{p}<0.001)$, histopathologic examination revealed a significant $(\mathrm{p}<0.001)$ delayed epithelization and decreased in fibrosis, vascularization, inflammation $(\mathrm{p}<0.001)$ in the experimental group. Conclusion: Enoxaparin delay wound healing by decreased inflammatory cells, fibroblast contents and their products (growth factors), and by promoted hemorrhage.
\end{abstract}

Key words: Heparin, Low-Molecular-Weight. Wound Healing. Rats.

\section{RESUMO}

Objetivo: Investigar o efeito de dose profilática da heparina de baixo peso molecular, enoxaparina, na cicatrização de feridas na pele de ratos. Métodos: Quarenta ratos foram utilizados para o estudo. Ratos foram distribuídos aleatoriamente a dois grupos iguais. O grupo experimental recebeu profilática de enoxaparina. Solução salina fisiologica foi administrada ao grupo controle. Foram comparados parâmetros de cicatrização dos grupos experimental e controle.Os grupos foram comparados em termos de fibrose, vascularização, inflamação, epitelização e força tensil (teste de Newton). Foi realizado o teste de Mann-Whitney-U para variáveis com dados categóricos (fibrose, cicatrização, inflamação e epitelização). Diferenças entre os grupos foram analisadas como amostras independentes pelo $t$-teste (força tensil). Significância foi fixada para $\mathrm{p}<0,05$. Resultados: A ferida do grupo experimental apresentou força tensil diminuída significativamente $(\mathrm{p}<0,001)$, o exame histopatológico revelou um significativo $(\mathrm{p}<0,001)$ retardo na epitelização e diminuição na fibrose, cicatrização, inflamação $(\mathrm{p}<0,001)$ no grupo experimental. Conclusão: A enoxaparina retarda a cicatrização da ferida pela diminuição das células inflamatórias, pelo menor conteúdo de fibroblasto e seus produtos (fatores de crescimento) e por promover hemorragia. O grupo experimental foi incluído pela perda significativa da força tênsil no presente estudo.

Descritores: Heparina de Baixo Peso Molecular. Cicatrização de Feridas. Ratos.

${ }^{1}$ Research performed at the Experimental Animal Laboratory, Faculty of Medicine, University of Ankara, Turkey.

\section{Introduction}

Deep vein thrombosis occurs in $50 \%$ to $70 \%$ of patients undergoing major lower limb orthopedics surgery, in patients with acute spinal injury or multiple traumas without prophylaxis ${ }^{1}$. After almost three decades of intensive research, low-molecularweight heparins (LMWH) have established their niche as an important class of antithrombotic compounds. LMWHs have become the gold standard for thromboprophylaxis in orthopedic surgery in our country.
Wound healing is influenced by numerous systemic and local factors. Wounding is immediately followed by coagulation, and during thrombus formation platelet factors that enhance fibroblast migration and proliferation are released ${ }^{2}$. Immediately after injury and clotting of the extravasated blood, inflammatory cells accumulate within the wounded area. Wound fluids conditioned by these cells were shown to contain mitogenic and angiogenic activities. After 18-24 hours epidermal cells migrate from the surrounding wound margins into the wounded area. Distal to the wound margins an increase in epidermal mitotic 
activity is observed resulting in sufficient cell divisions to fill and restore the original structure ${ }^{3}$.

LMWH exert their anticoagulant activity by activating antithrombin (previously known as antithrombin III). The relative importance of inhibition of factor Xa and inhibition of thrombin in mediating the antithrombotic effect of LMWH is unclear, but there is evidence that both are necessary. The pharmacokinetic characteristic can be explained by the decreased propensity of the former to bind to plasma proteins, endothelial cells, and macrophages. Firstly, LMWH inhibit platelet function because they bind platelets. Secondly, LMWH increase microvascular permeability. Thirdly, because of their affinity for endothelial cells, von Willebrand factor, and platelets, LMWH are likely to interfere with the interaction between platelets and vessel walls ${ }^{3}$. Therefore, we thought that LMWH lead to increased wound fluid and delayed wound healing. The results reported here strongly support this hypothesis.

The aim of the present study was to determine if LMWH influences the healing of skin wounds in animal model.

\section{Methods}

The study was approved by Ankara University School of Medicine Animal care and Use Committee. Forty Wistar albino rats weighing between 280 to $330 \mathrm{~g}$ were used in this study. In a temperature controlled and ventilated room with a light-dark cycle, animals were housed for at least 10 days before experiments and were given unlimited access to food and water. Rats were randomly assigned to two equal groups of twenty animals each on the experiment day. Experimental group received $1 \mathrm{XaI}$ unit/g body weight enoxaparin ${ }^{2}$. Subcutaneously once daily injections were begun 12 hours before skin incision, 6 hours after surgery and continued postoperative period until sacrificed. Physiologic saline $(0.5 \mathrm{ml})$ was administered to the control group. Operation was conducted in all groups under general anesthesia. The rats were anesthetized with intraperitoneal thiopental $100 \mathrm{mg} / \mathrm{kg}$. After induction of general anesthesia, the proximal leg regions of the rats were shaved and depilated. Surgical field was disinfected with povidoneiodine. All surgical procedures were performed under aseptic conditions by the same surgeons. A $3.0 \mathrm{~cm}$, full-thickness, longitudinal skin incision was established. Muscular fascia was exposed and blunt dissection was performed on lateral femoral muscles. The skin incision was sutured with interrupted $4 / 0$ nylon sutures. We preferred incisional wound rather than excisional, because in case of the latter there is usually initial-lag-phase for reepithelization ${ }^{4}$. Sutures were removed on post-operative day $14^{\text {th }}$. The rats, experimental and control were sacrificed on day $15^{\text {th }}$ after the operation.

The wound area was dissected and cut into $1.0 \times 2.0 \mathrm{~cm}$ longitudinal full-thickness strip without any undesirable mechanical damage of the sample. For histopathologic examinations $1 \mathrm{~cm}^{2}$ pieces of wound were obtained from the distal to the wound margins. Samples were fixed in $10 \%$ formaldehyde, embedded in paraffin, sectioned perpendicular to the wound and stained with hematoxylin-eosin for later analysis. Histological samples were examined using light microscopy (40x) and scored

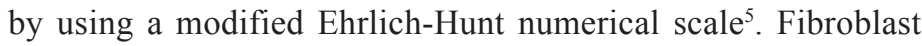
content, vascularity, and inflammatory cell infiltration were graded as 0 for absence, 1 for occasional presence and light scattering, 2 for abundance, and 3 for confluence of cells and fibers. Epithelial regeneration was scored as 0 for no epithelium, 1 for single-layer epithelium with partial closure, and 2 for multilayer epithelium with complete closure ${ }^{6}$. The same pathologist who was not informed on the groups of sections, evaluated the samples histopathologic examinations.

Tensile strength test: Skin tensile strengths were tested in a specially constructed tensiometer testing machine which provided a constantly increasing force in both groups. The skin sample was connected vertically between two claps of the tensiometer. Tensile strength was calculated as the maximum breaking strength divided by the incision area of the skin sample (Newton). Incision area was calculated as the product of the area subjected to testing between the clamps and the width of the specimen being tested.

\section{Statistical analysis}

Data were analyzed using SPSS for Windows v.13.0. Differences between groups were analyzed independent samples $t$-tests. For comparison of the groups in terms of fibrosis, vascularity, inflammation, and epithelization, Mann-Whitney-U test was used because variables were categorical data. Significance was set at $\mathrm{p}<0.05$.

\section{Results}

Fibrosis, inflammation, vascularity were significantly different between groups $(\mathrm{p}<0.001)$. The vascularity was significantly higher in the control group (Mean $\pm \mathrm{SD}, 3 \pm 0.6)$ compared with the experimental group (Mean \pm SD, $1 \pm 0.5)(\mathrm{P}<0.001)$. The inflammation was significantly lower in the experimental group $(0 \pm 0.5)$ compared with the control group (Mean $\pm \mathrm{SD}, 3 \pm 0.6$ ). The fibrosis was significantly higher in the control group $(3 \pm 0.6)$ compared with the experimental group (Mean $\pm \mathrm{SD}, 0 \pm 0.6)(\mathrm{p}<0.001)$. Epithelization was delayed significantly in experimental group (Mean $\pm \mathrm{SD}, 0 \pm 0.4$ ) compared with control group (Mean $\pm \mathrm{SD}$, $2 \pm 0.1)(\mathrm{p}<0.001)$. The values of histopathologic scores determined in the both groups are shown Table 1.

TABLE 1 - The values of histopathologic data were analyzed by Mann-Whitney U-tests

\section{Group 2 (control) Group 1 (enoxaparin) $\quad \mathrm{P}<$}

$(n=20) \quad(n=20)$

$\begin{array}{lccc}\text { Fibrosis } & 3 \pm 0.6 & 0 \pm 0.6 & 0.001 \\ \text { Vascularity } & 3 \pm 0.6 & 1 \pm 0.5 & 0.001 \\ \text { İnflammation } & 3 \pm 0.6 & 0 \pm 0.5 & 0.001 \\ \text { Epithelization } & 2 \pm 0.1 & 0 \pm 0.4 & 0.001\end{array}$


The tensile strengths were 17.5 \pm 5.7 Newton (mean \pm SD) in the experimental group and 54.8 \pm 6.4 Newton (mean \pm SD) in the control group $(\mathrm{p}<0.001)$ (Figure 1).
Epithelization is shown by photomicrographs (HEx40) in the enoxaparin group and control group (Figures 2 and 3).

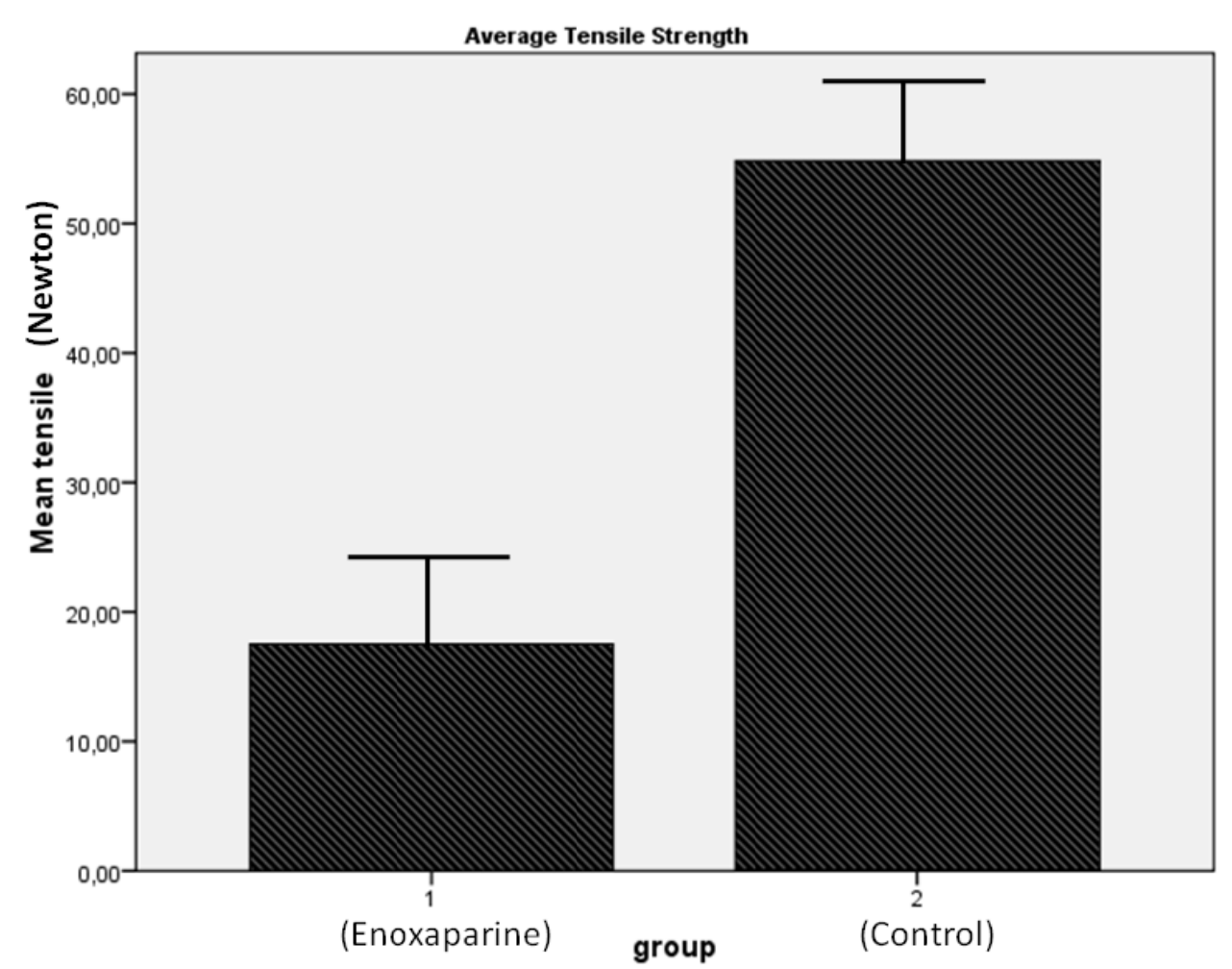

FIGURE 1 - Average tensile strength tests (Newton) from rats treated with enoxaparin group (1) and saline group (2) were analyzed by $t$-test $(\mathrm{p}<0.001)$

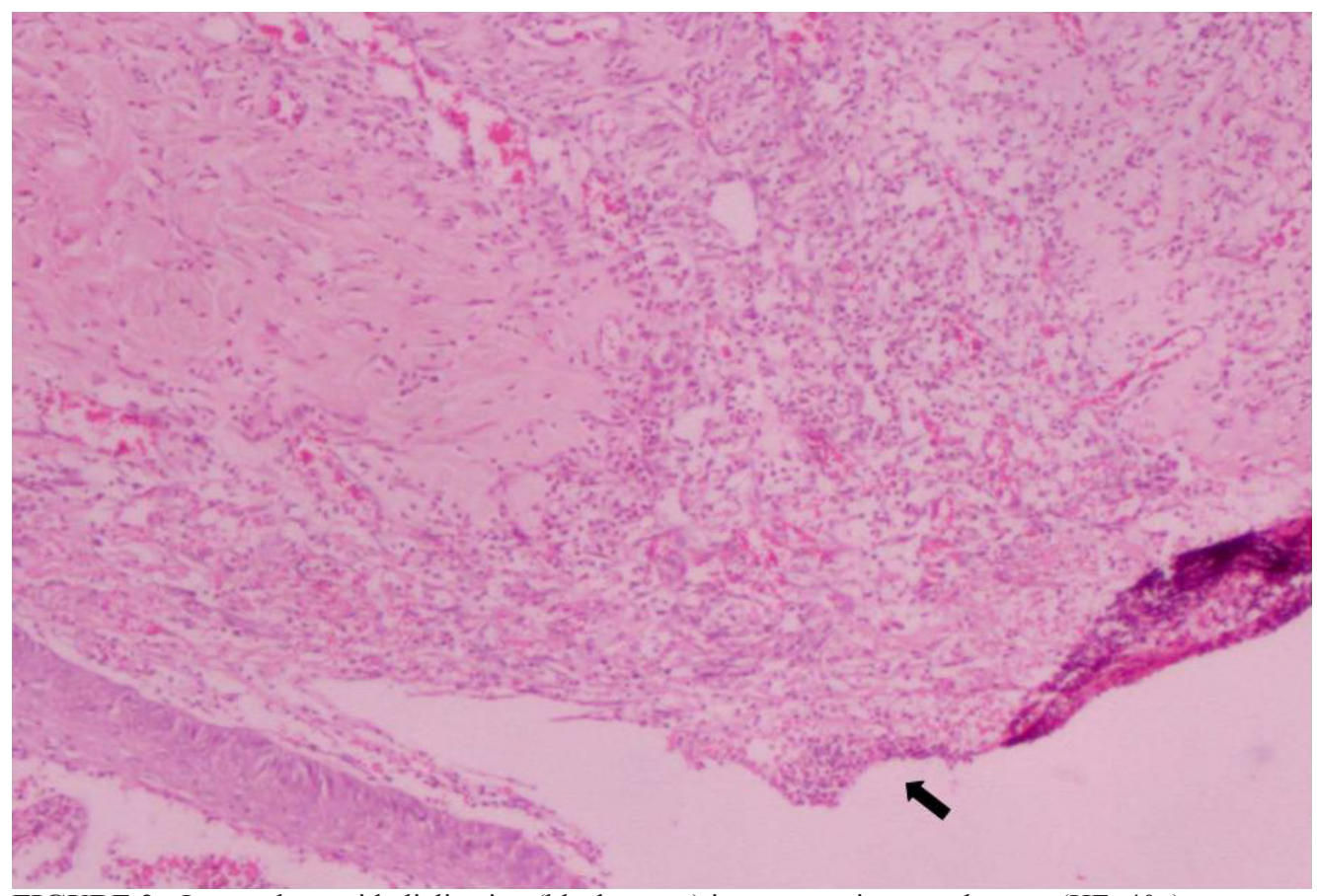

FIGURE 2 - Incomplete epithelialization (black arrow) in enoxaparin treated group (HE, 40x) 


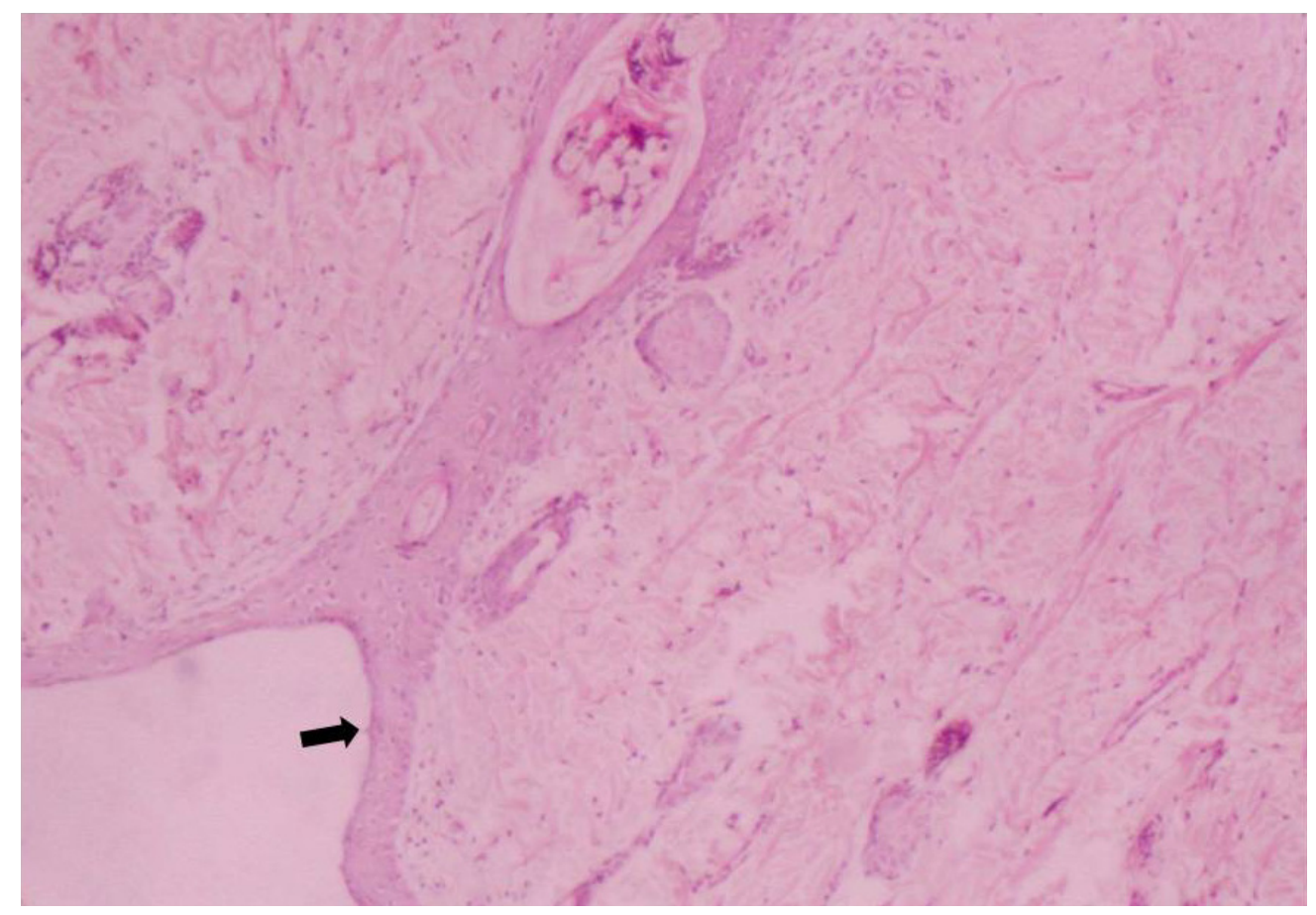

FIGURE 3 - Completed epithelialization (black arrow) in saline treated group (HE, 40x)

\section{Discussion}

Low-molecular-weight heparin (LMWH) is an important molecule which had been using in prophylaxis of deep venous thrombosis in patients. LMWHs are replacing heparins for many indications in Europe and for limited indications in North America ${ }^{1}$.

Using incisional wound model in rats, the current study shows that prophylactic dose of enoxaparin injection resulted in significant delay in epithelization at $15^{\text {th }}$ day after injury, and it caused significant difference in inflammation, fibrosis and vascularity $(p<0.001)$ under provided study conditions. The epithelization is the first to get completed in parameters of primary wound healing ${ }^{7}$ We might have changed only mechanism related with it, by using short-term prophylactic dose of enoxaparin. In previous studies shown that wound healing delays related to warfarin and heparin ${ }^{8-10}$. Lemke, in a prospective, randomized study, including 108 patients investigated the effect of different locations for the subcutaneous injection of LMWH and concluded that in abdominal injections before abdominal operations local surgical complications were four times higher compared to those patients with injections to the thigh ${ }^{11}$.

There have been isolated reports of wound healing disorders caused by LMWHs. Breaking strength or tensile strength is an important tool for evaluating wound healing effects of drugs $^{12}$. Matzsch ${ }^{2}$ showed that the breaking strength of colonic anastomosis in rats significantly increased after cessation of LMWH administration. In contrast to Ergul et al. ${ }^{13}$ reported that enoxaparin, especially in the deep venous thrombosis prophylaxis dose with subcutan application daily, did not only interfere with colonic anastomotic resistance but also improved the intestinal wound healing in rats. We consider that this difference between two results may be based on the difference between doses of drugs used in two research.

Although rarely described for LMWHs, enoxaparin induced skin necrosis has recently been reported ${ }^{14}$. the use of enoxaparin caused an increase on the tensile breaking strength and worse collagen disposition at the $7^{\text {th }}$ postoperative day ${ }^{15}$. Experimental group was included significant loss of tensile strength in our study.

LMWH thromboprophylaxis was associated with a significant increase in hemorrhagic complications after surgery ${ }^{16}$. When administering enoxaparin, there was more sero-hemorrhagic drainage on day 3 . In the presence of fibrin and platelet rich plasma, reepithelization rate significantly accelerates ${ }^{17}$. Prolonged sero-hemorrhagic drainage might have changed the content of wound fluid in enoxaparin treated group and so it influenced epithelialization.

Wound healing may be considered as one of the activities of hemostasis. Interstitial cells are making subsequent epithelization easy. The healing involves local chemotaxis, differentiation and proliferation together with regulation by physical and chemical mediators. Wound healing and tissue repair processes require synergism of systemic and local factors. Many growth factors as mentioned earlier play a role in it. Physiological repair occurs in a good systemic immune function, nutrition, normal local circulation without hemorrhage, edema and infection ${ }^{9,18,19}$.

Interruption to healing and repair cascades sometimes becomes useful. The use of LMWHs for the treatment of proliferative vitro-retinopathy patients is a good example for this statement. When compared with normal heparin, LMWHs were at least as effective in inhibiting proliferation and cell mediated contraction in vitro by both retinopigmental epithelial cells and ocular fibroblasts ${ }^{20}$. As shown by a study that LMWH inhibits vessel formation in placental explants ${ }^{21}$, the negative effect of LMWHs on angiogenesis helps in chemotheraphy by avascularization of tumoral lesion ${ }^{3}$. Evaluating the effects of LMWHs on cellular proliferation after experimental balloon angioplasty in rabbits, Henke et al. ${ }^{22}$ expressed that proliferative 
response after angioplasty could be reduced in vivo by early treatment with LMWHs. This effect is used in humans for the same purpose and for the prevention of restenosis after by-pass graft operations $^{3}$. In wound healing, however, angiogenesis is a necessary phase. Exogenous application of VEGF increases early angiogenesis and tensile strength even in the ischemic wounds ${ }^{23}$.

\section{Conclusion}

Enoxaparin delay wound healing by decreased inflammatory cells, fibroblast contents and their products (growth factors), and by promoted hemorrhage.

\section{References}

1. Street JT, McGrath M, O’ Regan K, Wakai A, McGuinness A, Redmond HP. Thromboprophylaxis using a low molecular weight heparin delays fracture repair. Clin Orthop Relat Res. 2000;(381):278-89.

2. Matzsch T, Bergqvist D, Blomquist P, Jiborn H. ?nfluence of standard heparin or low molecular weight heparin on healing of abdominal wounds and colonic anastomoses in rats. Acta Chir Scand. 1987;153(10):593-8.

3. Weitz JI. Low molecular weight heparins. N Eng1 J Med. 1997;337(10):688-98.

4. Wysocki AB. Wound measurement. Int J Dermatol. 1996;35(2):82-91. 5. Ehrlich HP, Tarver H, Hunt TK. Effects of vitamin A and glucocorticoids upon inflammation and collagen synthesis. Ann Surg. 1973;177(2):222-7.

6. Loewen MS, Walner DL, Caldarelli DD. Improved airway healing using transforming growth factor beta-3 in a rabbit model. Wound Repair Regen. 2001;9(1):44-9.

7. Schaffer CJ, Nanney LB. Cell biology of wound healing. Int Rev Cytol. 1996;169:151-81.

8. Andereya S, Kalicke T, Hopf KF, Buschmeier M, Muhr G. Serious complication after subcutaneous injection of heparin for prophylaxis of thromboembolism. Unfallchirurg. 2003;106(2):182-3

9. Burns JL, Mancoll JS, Phillips LG. Impairments to wound healing. Clin Plast Surg. 2003;30:47-56.

10. Salvati EA, Lachiewicz P. Thromboembolism following total hip-replacement arthroplasty. The efficacy of dextran-aspirin and dextran-warfarin in prophylaxis. J Bone Joint Surg Am. 1976;58:921-5. 11. Lemke H, Imhoff M, Lohlein D. Increased wound healing disorders in patients with inguinal hernia caused by administration of antithrombotic agents in the abdominal wall. Chirurg. 1994; 65(8):714-6.
12. Seveljevic-Jaran D. Wound healing: methods and protocols. Inflamm Res. 2003;52(11):441-2.

13. Ergul E, Ozgun YM, Kiyak G, Barit Ozgun G, Korukluoglu B, Kusdemir A. Does low molecular weight heparin impair anastomotic wound healing? J Gastrointest Surg. 2009;13(4):798-803.

14. Scharf Y, Hershkoviz R. Enoxaparin induced skin necrosis. Harefuah. 2003;142(11):742-3, 807

15. Oliveira PG, Sousa JB, Reys LG, Magalhães AV, Rabelo Fde S, Muniz KC. Effects of enoxaparin on the healing of abdominal wall in rats: study on breaking strength and histopathology. Acta Cir Bras. 2006;21(4):247-51. 16. Hardy RG, Williams L, Dixon JM. Use of enoxaparin results in more haemorrhagic complications after breast surgery than unfractionated heparin. Br J Surg. 2008;95(7):834-6.

17. Laplante AF, Germain L, Augner FA, Moulin V. Mechanisms of wound reepithelialization: hints from a tissue-engineered reconstructed skin to long-standing questions. Faseb J. 2001;15(13):2377-89.

18. Wang Z, Jiang J. Wound healing research in the new century. Chin Med J (Engl). 2000;113(4):383-4.

19. Weimann BJ, Hermann D. Studies on wound healing effects of calcium D-pantothenate on migration, proliferation and protein synthesis of human dermal fibroblasts in culture. Int J Vitam Nutr Res. 1999;69(2):113-9.

20. Iverson DA, Daily WA, Hartzer M, Chapman C. The effect of low molecular weight heparin on the mitogenicity of intraocular fluid from patients with proliferative ratinopathies. Invest Ophthalmol Vis Sci. 1991;32(Suppl):819.

21. Khorana AA, Sahni A, Altland OD, Francis CW. Heparin inhibition of endothelial cell proliferation and organization is dependent on molecular weight. Arterioscler Thromb Vasc Biol. 2003;23(11):2110-5.

22. Hanke H, Oberhoff M, Hanke S, Hassenstein S, Kamenz J, Schmid KM, Betz E, Karsch KR. Inhibition of cellular proliferation after experimental balloon angioplasty by low molecular weight heparin. Circulation. 1992;85(4):1548-56.

23. Zhang F, Lei MP, Oswald TM. The effect of vascular endothelial growth factor on the healing of ischemic skin wounds. Br J Plast Surg. 2003;56(4):334-41.

\section{Acknowledgements}

The authors wish to thank Feza Korkusuz, MD (Middle East Technical University, Medical Center, Ankara, Turkey) for critical reading of the manuscript.

\section{Correspondence:}

Conflict of interest: none Dr. O. Fuad OKEN

Serdar Sok. No:70/3

Yenimahalle / Ankara / Turkey

06170

Phone: (GSM): +905334811659

Fax: +903123632705

fuadoken@yahoo.com

Financial source: none

\section{How to cite this article}

Oken OF, Yildirim AO, Gulcek M, Unal VS, Karakuyu A, Ozlu K, Ucaner A. The effect of prophylactic dose of a low molecular weight heparin on skin wound healing of rats. Acta Cir Bras. [serial on the Internet] 2009 Nov-Dec;24(6).

Available from URL: http://www.scielo.br/acb 